\title{
Hydrogen peroxide inhibits the growth of lung cancer cells via the induction of cell death and G1-phase arrest
}

\author{
WOO HYUN PARK

\begin{abstract}
Department of Physiology, Medical School, Research Institute for Endocrine Sciences, Chonbuk National University, Jeonju, Jeollabuk 54907, Republic of Korea
\end{abstract}

Received January 2, 2018; Accepted June 21, 2018

DOI: 10.3892/or.2018.6535

\begin{abstract}
Hydrogen peroxide $\left(\mathrm{H}_{2} \mathrm{O}_{2}\right)$ is frequently applied to cultured cells to induce oxidative stress. The present study investigated the molecular and cellular effects of exogenous $\mathrm{H}_{2} \mathrm{O}_{2}$ on Calu-6 and A549 lung cancer cells. Based on MTT assays, $\mathrm{H}_{2} \mathrm{O}_{2}$ inhibited the growth of Calu- 6 and A549 cells with $\mathrm{IC}_{50}$ values of $\sim 50$ and $100 \mu \mathrm{M}$ at $24 \mathrm{~h}$, respectively. Cells treated with $\mathrm{H}_{2} \mathrm{O}_{2}$ demonstrated a considerable G1-phase arrest of the cell cycle. $\mathrm{H}_{2} \mathrm{O}_{2}$ dose-dependently augmented the numbers of dead (trypan blue-positive) and Annexin V-FITC-stained cells in these cells, which was accompanied by the reduction of $\mathrm{Bcl}-2$ and pro-caspase- 3 levels, as well as the upregulation of caspase- 3 and -8 activities. In addition, $\mathrm{H}_{2} \mathrm{O}_{2}$ triggered the failure of mitochondrial membrane potential (MMP; $\Delta \Psi_{\mathrm{m}}$ ). However, relatively higher doses of $\mathrm{H}_{2} \mathrm{O}_{2}$ did not raise the percentages of sub-G1 cells in these cell lines. All the tested caspase inhibitors (Z-VAD for pan-caspases, Z-DEVD for caspase-3, Z-IETD for caspase-8 and Z-LEHD for caspase-9) decreased the percentages of sub-G1 and Annexin V-FITC-stained cells in the $\mathrm{H}_{2} \mathrm{O}_{2}$-treated Calu-6 and A549 cells. However, caspase inhibitors did not significantly prevent the loss of MMP $\left(\Delta \Psi_{\mathrm{m}}\right)$ in $\mathrm{H}_{2} \mathrm{O}_{2}$-treated lung cancer cells. In conclusion, $\mathrm{H}_{2} \mathrm{O}_{2}$ inhibited the growth
\end{abstract}

Correspondence to: Professor Woo Hyun Park, Department of Physiology, Medical School, Chonbuk National University, 20 Geonji-ro, Deokjin, Jeonju, Jeollabuk 54907, Republic of Korea E-mail: parkwh71@jbnu.ac.kr

Abbreviations: $\mathrm{H}_{2} \mathrm{O}_{2}$, hydrogen peroxide; ROS, reactive oxygen species; NADPH, nicotinamide adenine dinucleotide phosphate; Z-VAD-FMK, benzyloxycarbonyl-Val-Ala-Asp-fluoromethyl ketone; Z-DEVD-FMK, benzyloxycarbonyl-Asp-Glu-Val-Asp-fluoromethyl ketone; Z-IETD-FMK, benzyloxycarbonyl-Ile-Glu-Thr-Aspfluoromethyl ketone; Z-LEHD-FMK, benzyloxycarbonyl-Leu-GluHis-Asp-fluoromethyl ketone; MMP $\left(\Delta \Psi_{\mathrm{m}}\right)$, mitochondrial membrane potential; MTT, 3-(4,5-dimethylthiazol-2-yl)-2, 5-diphenyltetrazolium bromide; FITC, fluorescein isothiocyanate; PI, propidium iodide

Key words: lung cancer cells, $\mathrm{H}_{2} \mathrm{O}_{2}$, caspase inhibitors, cell growth, cell death of Calu-6 and A549 lung cancer cells through cell death and G1-phase arrest. $\mathrm{H}_{2} \mathrm{O}_{2}$-induced cell death resulted from necrosis, as well as caspase-dependent apoptosis.

\section{Introduction}

Reactive oxygen species (ROS) are highly unstable and reactive molecules containing oxygen moieties. They include hydrogen peroxide $\left(\mathrm{H}_{2} \mathrm{O}_{2}\right)$, superoxide anion $\left(\mathrm{O}_{2}{ }^{\bullet-}\right)$ and hydroxyl radical $\left({ }^{\bullet} \mathrm{OH}\right)$. Although ROS are recognized as cytotoxic agents, they can serve as second messengers to control many cellular events of gene expression, differentiation, cell proliferation and cell death $(1,2)$. ROS are continuously generated by endogenous aerobic metabolism within cells in the form of the $\mathrm{O}_{2}^{\bullet-}$ and/or are purposely made by oxidases, such as nicotinamide adenine dinucleotide phosphate (NADPH) oxidase and xanthine oxidase (3). $\mathrm{O}_{2}{ }^{\bullet-}$ is converted to $\mathrm{H}_{2} \mathrm{O}_{2}$ by the enzyme superoxide dismutase (4). $\mathrm{H}_{2} \mathrm{O}_{2}$ is further processed into $\mathrm{O}_{2}$ and $\mathrm{H}_{2} \mathrm{O}$ by catalase or glutathione peroxidases (5). Compared with other members of ROS, non-radical $\mathrm{H}_{2} \mathrm{O}_{2}$ is able to freely penetrate cell membranes, and it interacts with ferrous iron (Fenton chemistry), which produces the highly destructive and short-lived $\bullet \mathrm{OH}$. The production of different forms of ROS at various levels can be either useful or harmful to cells and tissues. Particularly, excessive amounts of ROS may be the outcome of either their overproduction and/or downregulation of antioxidants. Increased levels of ROS can result in damage to DNA, proteins and lipids in cells, implicating them in the etiology of several human diseases, including cancer (6-9).

Apoptosis is programmed cell death and occurs via two different pathways: The mitochondrial intrinsic pathway and the receptor mediated extrinsic pathway (10). The key step in the mitochondrial-mediated apoptosis is the translocation of cytochrome $c$ from mitochondria to cytosol and its subsequent interaction with Apaf-1 and caspase-9 to form a complex (apoptosome). The apoptosome further activates executive caspase-3, -6 and -7 (11). Conversely, the extrinsic pathway begins with the binding of specific ligands, such as TNF- $\alpha$, TRAIL and Fas to the respective cell death receptors, which stimulate the activities of caspase- 8 and -3 (12). Caspase- 8 cleaves BID, a pro-apoptotic cytosolic protein of the Bcl-2 family, to generate a truncated product, tBID that enters into the mitochondria and decreases the mitochondrial membrane potential (MMP; $\Delta \Psi_{\mathrm{m}}$ ), causing the release of cytochrome $c$. 
The translocation of another apoptotic protein, Bax from the cytosol to the mitochondria also triggers similar loss of MMP $\left(\Delta \Psi_{\mathrm{m}}\right)$. Caspase-3 is the key executive caspase; its activation can systematically disassemble the integrity of cells through cleaving several key proteins, such as poly(ADP-ribose) polymerase (PARP) and RhoGDI.

Lungs are susceptible to a variety of airborne and bloodborne injuries that may consequently cause lung fibrosis and cancer (13). The carcinogenesis of lung cancer is considered to be tightly linked to $\mathrm{H}_{2} \mathrm{O}_{2}$-mediated tissue inflammation. During inflammation, tissue concentrations of $\mathrm{H}_{2} \mathrm{O}_{2}$ are expected to achieve nearly millimolar levels, whereas low levels of $\mathrm{H}_{2} \mathrm{O}_{2}$ produced by NADPH oxidases under normal conditions are hypothesized not to have a higher affect than the plasma membrane microenvironment, such as lipid rafts $(14,15)$. Nonetheless, in both cases, $\mathrm{H}_{2} \mathrm{O}_{2}$ may modulate vital cellular functions of cell proliferation, death and differentiation by changing signaling cascades and gene expression and its higher levels may lead to apoptosis and/or necrosis. Exogenous $\mathrm{H}_{2} \mathrm{O}_{2}$ is frequently used as the representative ROS to simulate oxidative stress in cells and tissues. $\mathrm{H}_{2} \mathrm{O}_{2}$ is relatively non-toxic to the normal cells of human umbilical vein endothelial cells and human pulmonary artery smooth muscle cells $(16,17) . \mathrm{H}_{2} \mathrm{O}_{2}$-triggered cell death in lung cancer cells may have cytotoxicological research interest.

In the present study, the molecular effects of exogenous $\mathrm{H}_{2} \mathrm{O}_{2}$ on Calu-6 and A549 lung cancer cells were evaluated with respect to cell growth and death, as well as the anti-apoptotic effects of various caspase inhibitors were investigated in $\mathrm{H}_{2} \mathrm{O}_{2}$-treated lung cancer cells.

\section{Materials and methods}

Cell culture. The human lung cancer Calu-6 and A549 cell lines were purchased from the Korean Cell Line Bank (Seoul, Korea) and were cultivated in RPMI-1640 medium supplemented with $10 \%$ fetal bovine serum (FBS; Sigma-Aldrich; Merck KGaA, Darmstadt, Germany) and $1 \%$ penicillin-streptomycin (Gibco-BRL; Thermo Fisher Scientific, Inc., Waltham, MA, USA). These cells were regularly cultured in $100-\mathrm{mm}$ plastic tissue culture dishes (Nunc, Roskilde, Denmark) and harvested with a trypsin-EDTA solution (Gibco-BRL; Thermo Fisher Scientific, Inc.).

Reagents. $\mathrm{H}_{2} \mathrm{O}_{2}$ was obtained from Merck KGaA. Pan-caspase inhibitor (Z-VAD-FMK; benzyloxycarbonylVal-Ala-Asp-fluoromethyl ketone), caspase-3 inhibitor (Z-DEVD-FMK; benzyloxycarbonyl-Asp-Glu-Val-Asp-fluoromethylketone), caspase-9 inhibitor (Z-LEHD-FMK; benzyloxycarbonyl-Leu-Glu-His-Asp-fluoromethyl ketone) and caspase- 8 inhibitor (Z-IETD-FMK; benzyloxycarbonyl-Ile-Glu-Thr-Asp-fluoromethyl ketone) were purchased from R\&D Systems, Inc. (Minneapolis, MN, USA) and were dissolved in dimethyl sulfoxide (DMSO; Sigma-Aldrich; Merck KGaA). Cells were pre-incubated with each caspase inhibitor for $1 \mathrm{~h}$ before the $\mathrm{H}_{2} \mathrm{O}_{2}$ treatment as previously described (18).

Cell growth and cell number assays. Cell growth changes were evaluated by assessing 3-(4,5-dimethylthiazol-2-yl)-2, 5-diphenyltetrazolium bromide (MTT; Sigma-Aldrich; Merck KGaA) dye absorbance as previously described (19). Viable and dead cell numbers were determined by trypan blue cell staining method (20). Cells were exposed to the designated amounts of $\mathrm{H}_{2} \mathrm{O}_{2}$ with or without $15 \mu \mathrm{M}$ of each caspase inhibitor for $24 \mathrm{~h}$.

Cell cycle and sub-G1 cell analysis. Cell cycle and sub-G1 cell analysis were performed by propidium iodide (PI; Sigma-Aldrich; Merck KGaA) staining as previously described (20). Cells were exposed to the designated amounts of $\mathrm{H}_{2} \mathrm{O}_{2}$ with or without $15 \mu \mathrm{M}$ of each caspase inhibitor for 24 h. Cell cycle distributions were analyzed with a FACStar flow cytometer (Becton-Dickinson and Company, Franklin Lakes, NJ, USA)

Annexin V-FITC staining for cell death detection. Apoptotic cell death was verified by measuring cells stained with Annexin V-fluorescein isothiocyanate (FITC; Invitrogen; Thermo Fisher Scientific, Inc.) as previously described (20). Cells were exposed to the designated amounts of $\mathrm{H}_{2} \mathrm{O}_{2}$ with or without $15 \mu \mathrm{M}$ of each caspase inhibitor for $24 \mathrm{~h}$. Annexin V-FITC staining was analyzed with a FACStar flow cytometer (Becton-Dickinson and Company).

Assessement of MMP $\left(\Delta \Psi_{m}\right)$. MMP $\left(\Delta \Psi_{\mathrm{m}}\right)$ was evaluated by a rhodamine 123 fluorescent dye (Sigma-Aldrich; Merck KGaA) as previously described (21). Cells were exposed to the designated amounts of $\mathrm{H}_{2} \mathrm{O}_{2}$ with or without $15 \mu \mathrm{M}$ of each caspase inhibitor for $24 \mathrm{~h}$. Rhodamine 123 staining intensity was analyzed by a FACStar flow cytometer (Becton-Dickinson and Company). The absence of rhodamine 123 from the cells indicated the loss of $\mathrm{MMP}\left(\Delta \Psi_{\mathrm{m}}\right)$ in lung cancer cells. $\operatorname{MMP}\left(\Delta \Psi_{\mathrm{m}}\right)$ levels in cells not including MMP $\left(\Delta \Psi_{\mathrm{m}}\right)$-loss cells were expressed as the mean fluorescence intensity, which was estimated by CellQuest software (version 5.1; Becton-Dickinson and Company).

Western blot analysis. The changes in Bcl-2, caspase-3 and PARP in $\mathrm{H}_{2} \mathrm{O}_{2}$-treated cells were analyzed by western blotting. Briefly, $1 \times 10^{6}$ cells in $60-\mathrm{mm}$ culture dish (Nunc) were incubated with the designated amounts of $\mathrm{H}_{2} \mathrm{O}_{2}$ for $24 \mathrm{~h}$. Samples containing $20 \mu \mathrm{g}$ total protein were separated by 8 or $12.5 \%$ SDS-PAGE gel, transferred to Immobilon-P PVDF membranes (EMD Millipore, Billerica, MA, USA) by electroblotting and then probed with anti-Bcl-2, anti-caspase-3, anti-PARP and anti- $\beta$-actin antibodies (dilution 1:5,000; Santa Cruz Biotechnology, Santa Cruz, CA, USA). Membranes were treated with horseradish peroxidase-conjugated secondary antibodies (dilution 1:5,000; Cell signaling Technology, Inc.). Blots were developed by means of an ECL kit (Amersham Life Science, Arlington Heights, IL, USA).

Quantification of caspase-3 and -8 activities. The activities of caspase- 3 and -8 were evaluated by caspase- 3 and -8 colorimetric assay kits (R\&D Systems, Inc.) as previously described (20). In brief, $1 \times 10^{6}$ cells in $60-\mathrm{mm}$ culture dish (Nunc) were treated with $75 \mu \mathrm{M} \mathrm{H}_{2} \mathrm{O}_{2}$ for $24 \mathrm{~h}$. Samples containing $50 \mu \mathrm{g}$ total protein were used to assess caspase- 3 and -8 activities. 
A
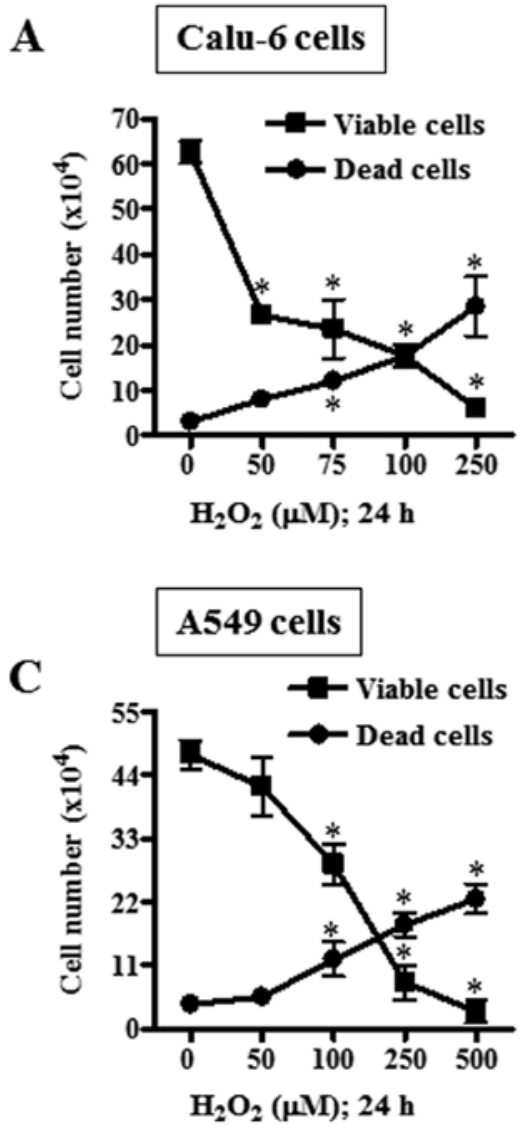

B

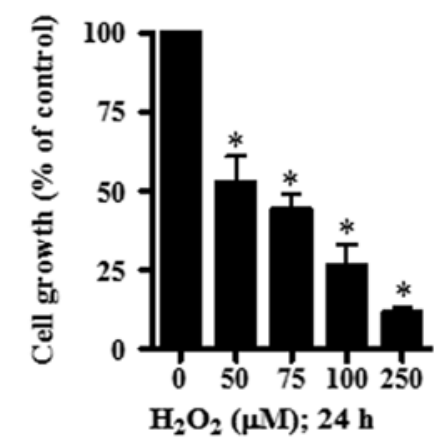

D

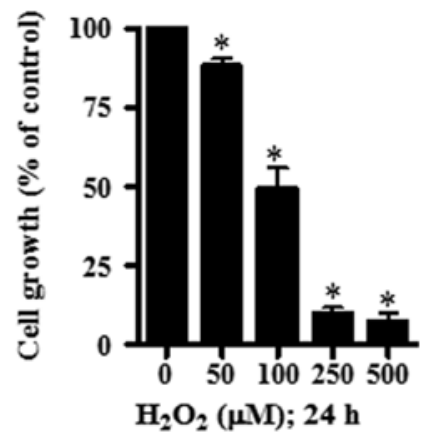

Figure 1. Effects of $\mathrm{H}_{2} \mathrm{O}_{2}$ on cell growth in lung cancer cells. Cells that exhibited adequate growth were treated with the designated amounts of $\mathrm{H}_{2} \mathrm{O}_{2}$ for 24 h. (A) Graph shows the viable (trypan blue-negative) and dead (trypan blue-positive) Calu-6 cell numbers. (B) Graph shows cellular growth changes in Calu-6 cells as assessed by MTT assays. (C) Graph shows the viable and dead A549 cell numbers. (D) The graph indicates cellular growth changes in A549 cells. * $\mathrm{P}<0.05$ compared with the $\mathrm{H}_{2} \mathrm{O}_{2}$-untreated control group. $\mathrm{H}_{2} \mathrm{O}_{2}$, hydrogen peroxide.

Statistical analysis. Data representing at least two independent experiments (mean \pm SD) were analyzed through InStat software (GraphPad Prism4; GraphPad Software, Inc., San Diego, CA, USA). The Student's t-test or one-way analysis of variance (ANOVA) with post hoc analysis using Tukey's multiple comparison test was used for parametric data. $\mathrm{P}<0.05$ was considered to indicate a statistically significant difference.

\section{Results}

$\mathrm{H}_{2} \mathrm{O}_{2}$ affects the cell growth and cycle distribution in lung cancer cells. The cellular effects of $\mathrm{H}_{2} \mathrm{O}_{2}$ on the growth of lung cancer cells were examined at $24 \mathrm{~h}$. Treatment with $50-250 \mu \mathrm{M}$ $\mathrm{H}_{2} \mathrm{O}_{2}$ significantly reduced viable (trypan blue-negative) and increased dead (trypan blue-positive) Calu- 6 cells in a dose-dependent manner (Fig. 1A). Based on MTT assays, 50-250 $\mu \mathrm{M} \mathrm{H}_{2} \mathrm{O}_{2}$ significantly attenuated the growth of Calu- 6 cells with an $\mathrm{IC}_{50}$ of $\sim 50 \mu \mathrm{M}$ (Fig. 1B). When the cell cycle distribution in $\mathrm{H}_{2} \mathrm{O}_{2}$-treated Calu- 6 cells was examined, Calu-6 cells treated with $75-\mu \mathrm{M} \mathrm{H}_{2} \mathrm{O}_{2}$ demonstrated a significant G1-phase arrest of the cell cycle compared with the control cells (Fig. 2A and B). As in Calu-6, upon $\mathrm{H}_{2} \mathrm{O}_{2}$ treatment, the number of A549 viable cells decreased and dead cells increased significantly in a dose-dependent manner (Fig. 1C). In addition, $\mathrm{H}_{2} \mathrm{O}_{2}$ dose-dependently reduced the growth of A549 cells with an $\mathrm{IC}_{50}$ of $\sim 100 \mu \mathrm{M}$ (Fig. 1D). Treatment with
$100 \mu \mathrm{M} \mathrm{H}_{2} \mathrm{O}_{2}$ also significantly induced a G1-phase arrest in A549 cells compared with the control cells (Fig. 2A and B).

$\mathrm{H}_{2} \mathrm{O}_{2}$ influences cell death and MMP $\left(\Delta \Psi_{m}\right)$ in $\mathrm{H}_{2} \mathrm{O}_{2}$-treated lung cancer cells. Subsequently, the role of $\mathrm{H}_{2} \mathrm{O}_{2}$ in lung cancer cell death was further investigated to gain more understanding. While 50-100 $\mu \mathrm{M} \mathrm{H}_{2} \mathrm{O}_{2}$ significantly augmented the percentages of sub-G1 cells in Calu- 6 cells, $250 \mu \mathrm{M} \mathrm{H}_{2} \mathrm{O}_{2}$ did not increase the percentage of sub-G1 cells in these cells (Fig. 2A and C). However, treatment with 50-250 $\mu \mathrm{M} \mathrm{H}_{2} \mathrm{O}_{2}$ dose-dependently increased the numbers of Annexin V-FITC-stained cells in Calu-6 cells (Fig. 3A). When the effect of $\mathrm{H}_{2} \mathrm{O}_{2}$ on MMP $\left(\Delta \Psi_{\mathrm{m}}\right)$ in Calu- 6 cells was assessed using rhodamine $123, \mathrm{H}_{2} \mathrm{O}_{2}$ provoked the loss of $\mathrm{MMP}\left(\Delta \Psi_{\mathrm{m}}\right)$ in a dose-dependent manner (Fig. 3B). With regard to $\operatorname{MMP}\left(\Delta \Psi_{\mathrm{m}}\right)$ level in Calu- 6 cells excluding negative rhodamine 123 staining cells, $\mathrm{H}_{2} \mathrm{O}_{2}$ decreased the MMP $\left(\Delta \Psi_{\mathrm{m}}\right)$ level in Calu- 6 cells in a dose-dependent manner (Fig. 3C). In A549 cells, treatment of 50 and $100 \mu \mathrm{M} \mathrm{H}_{2} \mathrm{O}_{2}$ significantly increased the percentages of sub-G1 cells, but treatment with 250 and $500 \mu \mathrm{M} \mathrm{H}_{2} \mathrm{O}_{2}$ did not show this effect (Fig. 2A and C). $\mathrm{H}_{2} \mathrm{O}_{2}$ dose-dependently enhanced the numbers of Annexin V-FITC-stained A549 cells (Fig. 3D). Additionally, $\mathrm{H}_{2} \mathrm{O}_{2}$ dose-dependently induced the loss of MMP $\left(\Delta \Psi_{\mathrm{m}}\right)$ in A549 cells (Fig. 3E). While $50 \mu \mathrm{M}$ $\mathrm{H}_{2} \mathrm{O}_{2}$ increased MMP $\left(\Delta \Psi_{\mathrm{m}}\right)$ level in A549 cells, $100-250 \mu \mathrm{M}$ $\mathrm{H}_{2} \mathrm{O}_{2}$ significantly decreased MMP $\left(\Delta \Psi_{\mathrm{m}}\right)$ levels in these cells (Fig. 3F). 
$\mathbf{A}$
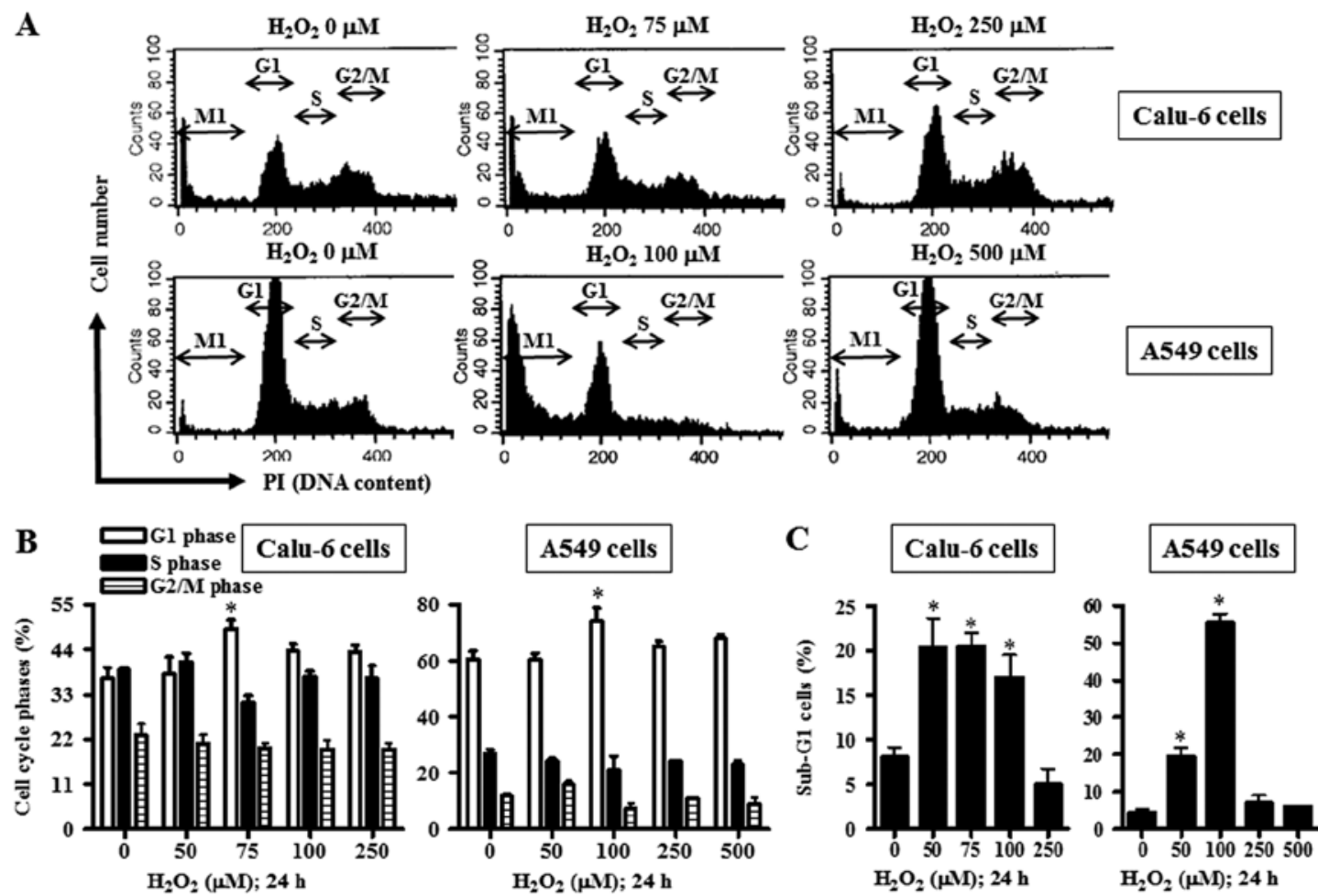

Figure 2. Effects of $\mathrm{H}_{2} \mathrm{O}_{2}$ on the cell cycle distribution in lung cancer cells. Cells that exhibited adequate growth were treated with the designated concentrations of $\mathrm{H}_{2} \mathrm{O}_{2}$ for $24 \mathrm{~h}$. (A) Representative images of cell cycle analysis, as analyzed by FACStar flow cytometer. M1 regions show sub-G1 cells; G1, S and G2/M regions indicate G1, S and G2/M phases of the cell cycle in Calu- 6 and A549 cells. (B) Graphs show the cell cycle distribution from G1, S and G2/M regions of A. (C) Graphs indicate the percentages of sub-G1 cells in M1 regions of A. " $\mathrm{P}<0.05$ compared with the $\mathrm{H}_{2} \mathrm{O}_{2}$-untreated control group. $\mathrm{H}_{2} \mathrm{O}_{2}$, hydrogen peroxide.

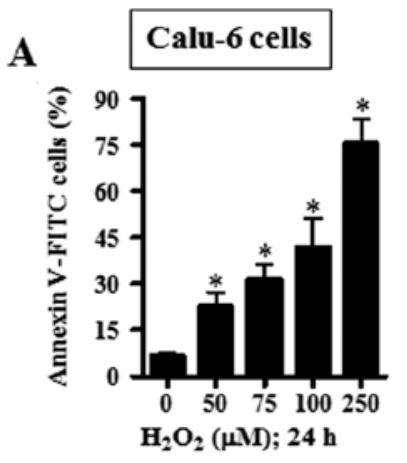

D

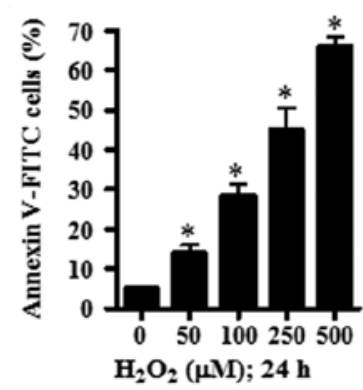

B

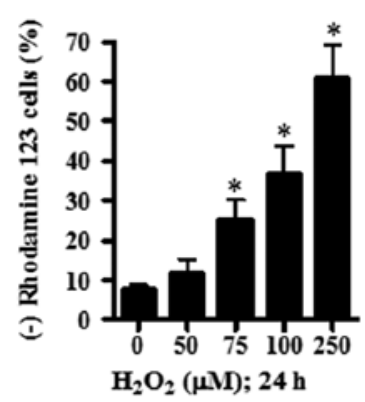

$\mathbf{E}$

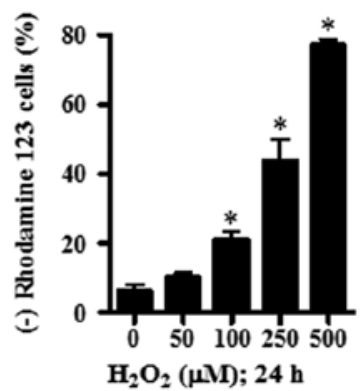

C

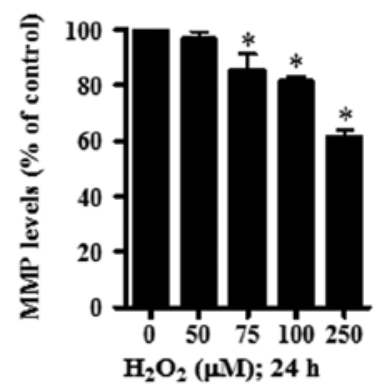

$\mathbf{F}$

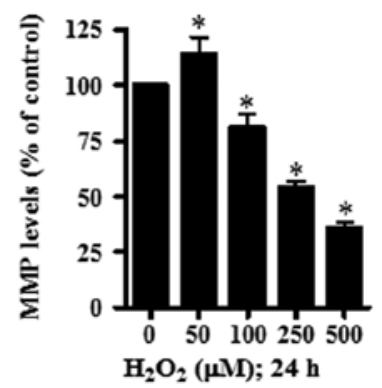

Figure 3. Effects of $\mathrm{H}_{2} \mathrm{O}_{2}$ on cell death and MMP $\left(\Delta \Psi_{\mathrm{m}}\right)$ in lung cancer cells. Cells that exhibited adequate growth were treated with the designated concentrations of $\mathrm{H}_{2} \mathrm{O}_{2}$ for $24 \mathrm{~h}$. (A and D) Graphs show the percentages of Annexin V-FITC-stained cells in Calu- 6 and A549 cells as measured by FACStar flow cytometer. (B and E) Graphs show the percentages of rhodamine 123-negative [MMP ( $\left.\Delta \Psi_{\mathrm{m}}\right)$ loss] Calu-6 and A549 cells as assessed by FACStar flow cytometer, respectively. ( $\mathrm{C}$ and F) Graphs represent the percentages of mean MMP $\left(\Delta \Psi_{\mathrm{m}}\right)$ levels in rhodamine 123 -stained Calu- 6 and A549, respectively. ${ }^{*} \mathrm{P}<0.05$ compared with the $\mathrm{H}_{2} \mathrm{O}_{2}$-untreated control group. $\mathrm{H}_{2} \mathrm{O}_{2}$, hydrogen peroxide; MMP, mitochondrial membrane potential.

$\mathrm{H}_{2} \mathrm{O}_{2}$ influences apoptosis-related proteins and caspases in $\mathrm{H}_{2} \mathrm{O}_{2}$-treatedlung cancercells. Assessment of apoptosis-related proteins during $\mathrm{H}_{2} \mathrm{O}_{2}$-induced lung cell death revealed that $\mathrm{Bcl}-2$, an anti-apoptotic protein, decreased upon $\mathrm{H}_{2} \mathrm{O}_{2}$ 
A

\section{Calu-6 cells}

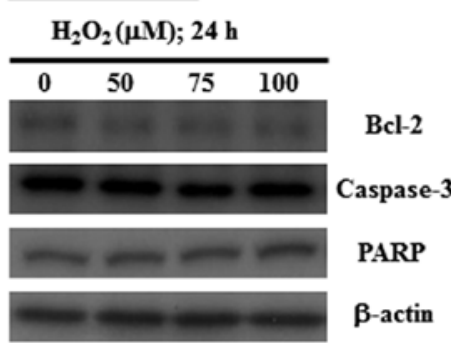

C

\section{A549 cells}

$\mathrm{H}_{2} \mathrm{O}_{2}(\mu \mathrm{M}) ; 24 \mathrm{~h}$

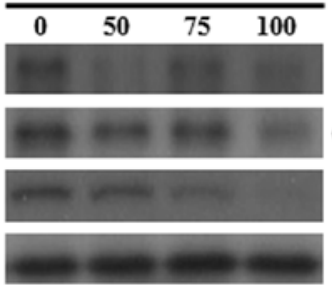

Bcl-2

PARP

$\beta$-actin
B

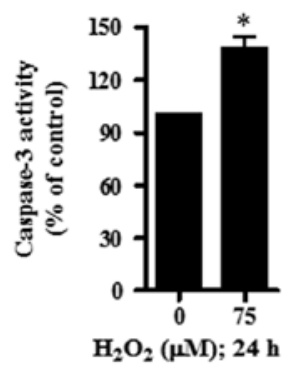

D

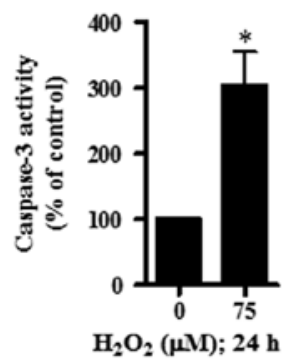

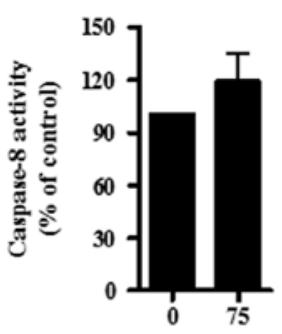

$\mathrm{H}_{2} \mathrm{O}_{2}(\mu \mathrm{M}) ; 24 \mathrm{~h}$

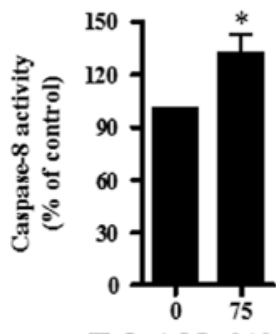

Figure 4. Effects of $\mathrm{H}_{2} \mathrm{O}_{2}$ on apoptosis-related proteins and caspases in $\mathrm{H}_{2} \mathrm{O}_{2}$-treated lung cancer cells. Cells that exhibited adequate growth were treated with the designated concentrations of $\mathrm{H}_{2} \mathrm{O}_{2}$ for $24 \mathrm{~h}$. (A and C) The western blot analysis data show the levels of Bcl-2, pro-caspase-3, PARP and $\beta$-actin in $\mathrm{H}_{2} \mathrm{O}_{2}$-treated Calu- 6 and A549 cells, respectively. (B and D) Graphs show the activities of caspase-3 and -8 in $\mathrm{H}_{2} \mathrm{O}_{2}$-treated Calu- 6 and A549 cells, respectively. ${ }^{*} \mathrm{P}<0.05$ compared with the $\mathrm{H}_{2} \mathrm{O}_{2}$-untreated control group. $\mathrm{H}_{2} \mathrm{O}_{2}$, hydrogen peroxide.

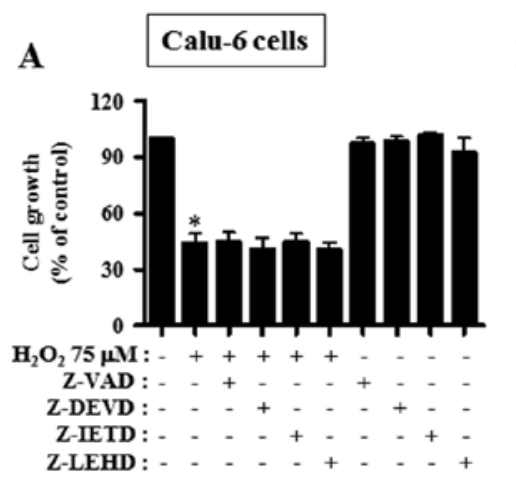

B

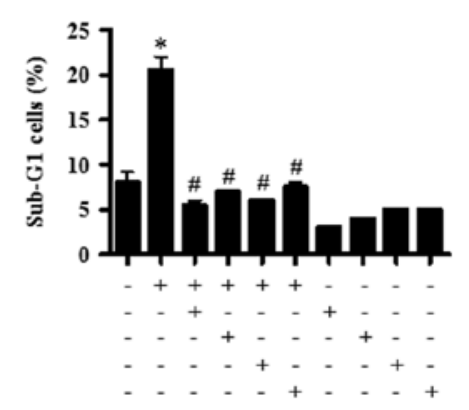

E

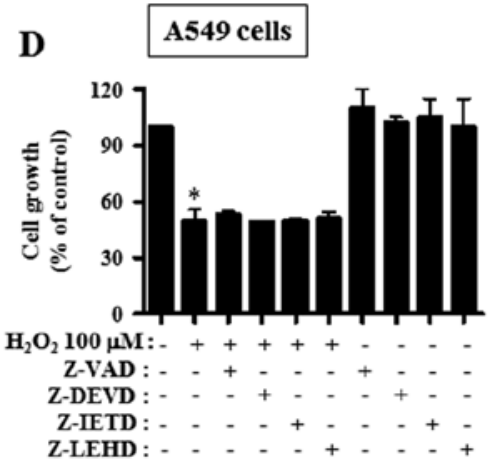

$\mathrm{H}_{2} \mathrm{O}_{2} 100 \mu \mathrm{M}:-+++++. .-2$

Z-VAD : - + - - + - -

Z-DEVD :

Z-LEHD :

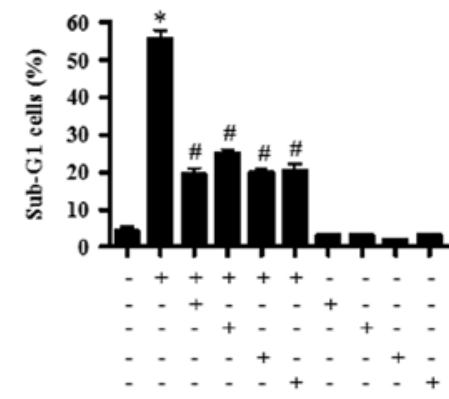

C

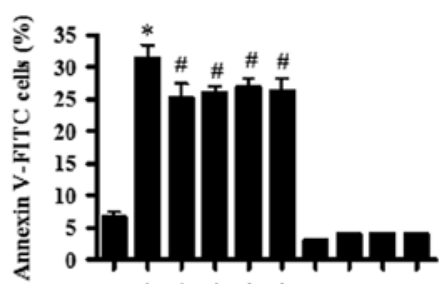

$\mathbf{F}$

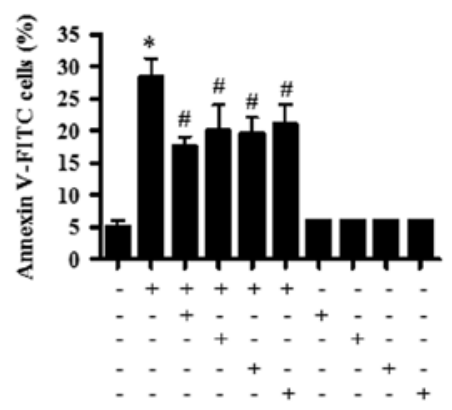

Figure 5. Effects of caspase inhibitors on cell growth and death in $\mathrm{H}_{2} \mathrm{O}_{2}$-treated lung cancer cells. Cells that exhibited adequate growth were treated with 75 or $100 \mu \mathrm{M} \mathrm{H}_{2} \mathrm{O}_{2}$ for $24 \mathrm{~h}$ following $1 \mathrm{~h}$ pre-treatment of $15 \mu \mathrm{M}$ caspase inhibitor. (A and D) Graphs show cellular growth changes in Calu-6 and A549 cells as assessed by MTT assays. (B and E) Graph show the percentages of sub-G1 cells in Calu- 6 and A549 cells as assessed by FACStar flow cytometer. (C and F) Graphs show the percentages of Annexin V-FITC-stained cells in Calu- 6 and A549 cells as assessed by FACStar flow cytometer. ${ }^{*} \mathrm{P}<0.05$ compared with the $\mathrm{H}_{2} \mathrm{O}_{2}$-untreated control group. ${ }^{*} \mathrm{P}<0.05$ compared with cells treated only with $\mathrm{H}_{2} \mathrm{O}_{2} \cdot \mathrm{H}_{2} \mathrm{O}_{2}$, hydrogen peroxide.

treatment in Calu-6 cells (Fig. 4A). The level of pro-caspase-3 was reduced by $75 \mu \mathrm{M} \mathrm{H}_{2} \mathrm{O}_{2}$ (Fig. 4A). The unbroken form of
$116 \mathrm{kDa}$ PARP was not altered by $\mathrm{H}_{2} \mathrm{O}_{2}$ (Fig. 4A). The activity of caspase-3 was found to be increased in $\mathrm{H}_{2} \mathrm{O}_{2}$-treated 

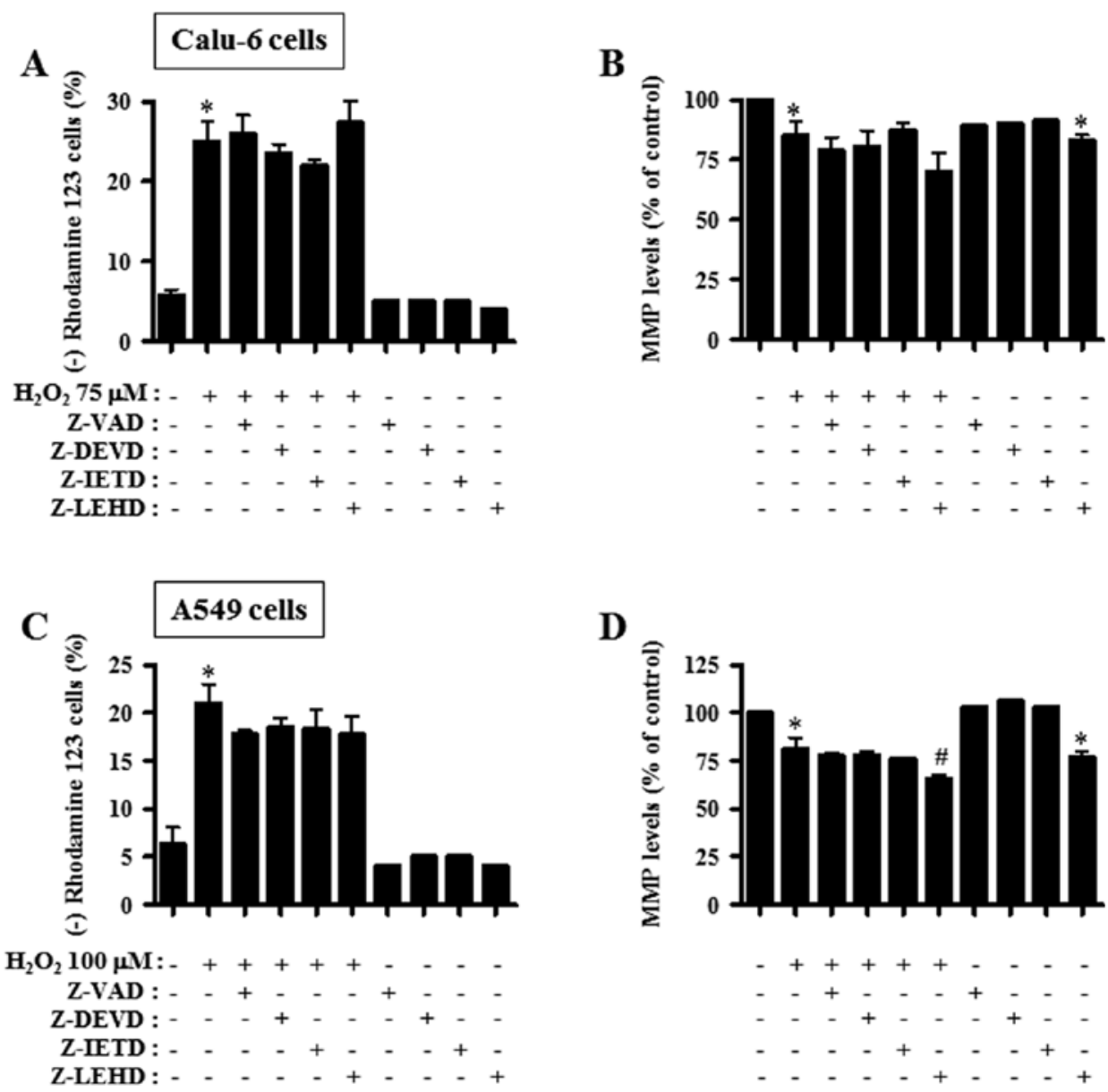

Figure 6. Effects of caspase inhibitors on MMP $\left(\Delta \Psi_{\mathrm{m}}\right)$ in $\mathrm{H}_{2} \mathrm{O}_{2}$-treated lung cancer cells. Cells that exhibited adequate growth were treated with 75 or $100 \mu \mathrm{M} \mathrm{H}_{2} \mathrm{O}_{2}$ for $24 \mathrm{~h}$ following $1 \mathrm{~h}$ pre-treatment of $15 \mu \mathrm{M}$ caspase inhibitor. (A and C) Graphs show the percentages of rhodamine 123-negative [MMP $\left(\Delta \Psi_{\mathrm{m}}\right)$ loss] Calu-6 and A549 cells as assessed by FACStar flow cytometer. (B and D) Graphs represent the percentages of mean MMP $\left(\Delta \Psi_{\mathrm{m}}\right)$ levels in rhodamine 123-stained cells of Calu-6 and A549. ${ }^{*} \mathrm{P}<0.05$ compared with the $\mathrm{H}_{2} \mathrm{O}_{2}$-untreated control group. ${ }^{*} \mathrm{P}<0.05$ compared with cells treated only with $\mathrm{H}_{2} \mathrm{O}_{2} . \mathrm{H}_{2} \mathrm{O}_{2}$, hydrogen peroxide; MMP, mitochondrial membrane potential.

Calu- 6 cells, while that of caspase- 8 was not significantly changed (Fig. 4B). Treatment with 50-100 $\mu \mathrm{M} \mathrm{H}_{2} \mathrm{O}_{2}$ appeared to decrease $\mathrm{Bcl}-2$, pro-caspase-3, and PARP protein levels in A549 cells (Fig. 4C). Specifically, $100 \mu \mathrm{M} \mathrm{H}_{2} \mathrm{O}_{2}$ showed a marked decrease in the levels of these proteins. Treatment with $75 \mu \mathrm{M} \mathrm{H}_{2} \mathrm{O}_{2}$ significantly augmented the activity of caspase- 3 in A549 cells and significantly increased the activity of caspase-8 (Fig. 4D).

Caspase inhibitors affect cell growth and death in $\mathrm{H}_{2} \mathrm{O}_{2}$-treated lung cancer cells. Subsequently we sought to decipher the role of individual caspases in $\mathrm{H}_{2} \mathrm{O}_{2}$-induced cell death at $24 \mathrm{~h}$ in lung carcinoma cell lines. Calu-6 and A549 cells were pre-incubated with $15 \mu \mathrm{M}$ caspase inhibitor for $1 \mathrm{~h}$ before treatment with 75 or $100 \mu \mathrm{M} \mathrm{H}_{2} \mathrm{O}_{2}$. None of the tested caspase inhibitors influenced the growth inhibition induced by $\mathrm{H}_{2} \mathrm{O}_{2}$ in both Calu-6 and A549 cell lines (Fig. 5A and D). However, all the caspase inhibitors tested in $\mathrm{H}_{2} \mathrm{O}_{2}$-treated Calu-6 decreased the percentages of sub-G1 cells to the level of the control cells (Fig. 5B). In addition, treatment with all the tested caspase inhibitors significantly reduced the number of Annexin V-FITC-stained cells in $\mathrm{H}_{2} \mathrm{O}_{2}$-treated Calu-6 cells, but the decreased effect was weaker compared with the decrease in sub-G1 cells (Fig. 5C). All the caspase inhibitors markedly rescued A549 cells from $\mathrm{H}_{2} \mathrm{O}_{2}$-promoted cell death, as assessed by the population of sub-G1 cells (Fig. 5E). Furthermore, these inhibitors significantly reduced the number of Annexin V-FITC-stained cells in $\mathrm{H}_{2} \mathrm{O}_{2}$-treated A549 cells (Fig. 5F). Each caspase inhibitor had very similar anti-death effects in the $\mathrm{H}_{2} \mathrm{O}_{2}$-treated lung cancer cells.

Caspase inhibitors affect MMP $\left(\Delta \Psi_{m}\right)$ in $\mathrm{H}_{2} \mathrm{O}_{2}$-treated lung cancer cells. Cell death is strongly associated with the collapse of MMP $\left(\Delta \Psi_{\mathrm{m}}\right)(22)$. Thus, MMP $\left(\Delta \Psi_{\mathrm{m}}\right)$ in 75 or $100 \mu \mathrm{M} \mathrm{H}_{2} \mathrm{O}_{2}$-treated lung cancer cells was determined with or without each caspase inhibitors at $24 \mathrm{~h}$. However, all the caspase inhibitors did not significantly reduce the loss of MMP $\left(\Delta \Psi_{\mathrm{m}}\right)$ in $\mathrm{H}_{2} \mathrm{O}_{2}$-treated Calu-6 cells (Fig. 6A). Additionally, most of these inhibitors did not influence the MMP $\left(\Delta \Psi_{\mathrm{m}}\right)$ level in $\mathrm{H}_{2} \mathrm{O}_{2}$-treated Calu- 6 cells. However, caspase-9 inhibitor (Z-LEHD) appeared to enhance the decrease of the level in these cells (Fig. 6B). In A549 cells, all the caspase inhibitors partially prevented the loss of MMP $\left(\Delta \Psi_{\mathrm{m}}\right)$ by $\mathrm{H}_{2} \mathrm{O}_{2}$ (Fig. $6 \mathrm{C}$ ). In $\mathrm{H}_{2} \mathrm{O}_{2}$-treated A549 cells, caspase-9 inhibitor selectively further enhanced the decrease in MMP $\left(\Delta \Psi_{\mathrm{m}}\right)$ level (Fig. 6D). This inhibitor alone significantly reduced MMP $\left(\Delta \Psi_{\mathrm{m}}\right)$ levels in Calu-6 and A549 control cells (Fig. 6B and D). 


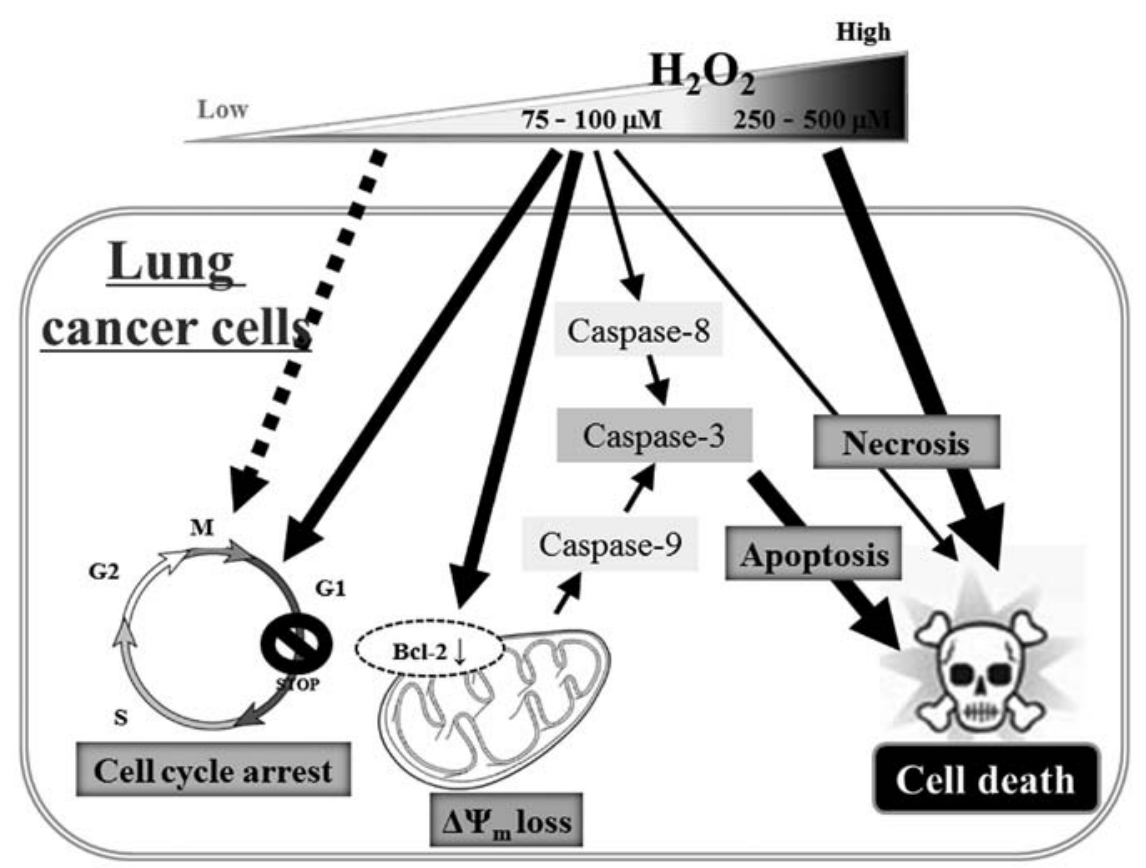

Figure 7. Schematic diagram representing the proposed cellular effects of $\mathrm{H}_{2} \mathrm{O}_{2}$ in lung cancer cells. $\mathrm{H}_{2} \mathrm{O}_{2}$, hydrogen peroxide; MMP ( $\Delta \Psi_{\mathrm{m}}$ ), mitochondrial membrane potential.

\section{Discussion}

Lung cancer represents one of the main causes of cancer-related mortality worldwide and is related to the malicious activity of ROS. In the present study, exogenous $\mathrm{H}_{2} \mathrm{O}_{2}$ was used for generating oxidative stress in lung cancer cells. This study focused on defining the molecular mechanisms of cell growth inhibition and cell death in $\mathrm{H}_{2} \mathrm{O}_{2}$-treated Calu- 6 and A549 lung cancer cells. Based on MTT assays, after 24-h exposure, the $\mathrm{IC}_{50}$ values for $\mathrm{H}_{2} \mathrm{O}_{2}$ were $\sim 50$ and $100 \mu \mathrm{M}$ in Calu-6 and A549 cells, respectively. $\mathrm{H}_{2} \mathrm{O}_{2}$ dose-dependently increased the number of dead and Annexin V-FITC-stained Calu-6 and A549 cells, indicating that $\mathrm{H}_{2} \mathrm{O}_{2}$-induced lung cancer cell death occurred through apoptosis. Evidently, $\mathrm{H}_{2} \mathrm{O}_{2}$ decreased the levels of Bcl-2 and pro-caspase-3 in both cell types. PARP was reduced in the $\mathrm{H}_{2} \mathrm{O}_{2}$-treated A549 cells. Furthermore, the activities of caspase- 3 and -8 were increased in both $\mathrm{H}_{2} \mathrm{O}_{2}$-treated cell types. Apoptosis is strongly related to the collapse of MMP $\left(\Delta \Psi_{\mathrm{m}}\right)(22) \cdot \mathrm{H}_{2} \mathrm{O}_{2}$ triggered the loss of MMP $\left(\Delta \Psi_{\mathrm{m}}\right)$ in Calu-6 and A549 cells in a dose-dependent manner, indicating that lung cancer cell death by $\mathrm{H}_{2} \mathrm{O}_{2}$ was closely related with the collapse of MMP $\left(\Delta \Psi_{\mathrm{m}}\right)$. In addition, $\mathrm{H}_{2} \mathrm{O}_{2}$ decreased the MMP $\left(\Delta \Psi_{\mathrm{m}}\right)$ level in lung cancer cells containing the rhodamine 123 dye.

Although 50-100 $\mu \mathrm{M} \mathrm{H}_{2} \mathrm{O}_{2}$ significantly increased the percentages of sub-G1 Calu- 6 and A549 cells, 250 or $500 \mu \mathrm{M}$ $\mathrm{H}_{2} \mathrm{O}_{2}$ did not demonstrate a similar effect, indicating that the higher doses of $\mathrm{H}_{2} \mathrm{O}_{2}$ fixed these lung cancer cells in a similar way to ethanol or methanol. Thus, $\mathrm{H}_{2} \mathrm{O}_{2}$ appeared to induce lung cancer cell death simultaneously via necrosis and apoptosis, depending on its concentration. In particular, 75 and $100 \mu \mathrm{M} \mathrm{H}_{2} \mathrm{O}_{2}$ appeared to concurrently trigger both apoptosis and necrosis in Calu- 6 cells, since these doses of $\mathrm{H}_{2} \mathrm{O}_{2}$ did not increase the percentages of sub-G1 cells compared with $50 \mu \mathrm{M} \mathrm{H}_{2} \mathrm{O}_{2}$-treated cells, as well as there was no change in the levels of the intact form of PARP protein. It is required to evaluate the activity of the extracellular lactate dehydrogenase in lung cancer cells treated with 50-500 $\mu \mathrm{M} \mathrm{H}_{2} \mathrm{O}_{2}$ for the detection of necrotic cell death. Previous studies revealed a role of $\mathrm{H}_{2} \mathrm{O}_{2}$ in cell-cycle phase arrest and progression by adjusting cell cycle-related proteins $(23,24)$. In line with this, treatment with 75 or $100 \mu \mathrm{M} \mathrm{H}_{2} \mathrm{O}_{2}$ among the tested doses significantly showed a G1 phase arrest in Calu-6 and A549 cells. Thus, the G1 phase arrest together with induction of cell death is the potential mechanism behind the attenuation of cell growth upon $\mathrm{H}_{2} \mathrm{O}_{2}$ treatment. However, $\mathrm{H}_{2} \mathrm{O}_{2}$ did not make any specific phase arrests of the cell cycle in HeLa cells (20). These results indicated that $\mathrm{H}_{2} \mathrm{O}_{2}$-induced oxidative stress manifested its effects on cell cycle progression depending on the cell type and $\mathrm{H}_{2} \mathrm{O}_{2}$ dose.

Caspase inhibitors used in this experiment failed to attenuate the growth inhibition in $\mathrm{H}_{2} \mathrm{O}_{2}$-treated Calu- 6 and $\mathrm{A} 549$ cancer cells, whereas these inhibitors considerably prevented $\mathrm{H}_{2} \mathrm{O}_{2}$-induced cell death in these cells. Although $\mathrm{H}_{2} \mathrm{O}_{2}$ to some extent augmented the activity of caspase- 8 in both lung cancer cells, caspase- 8 inhibitor significantly attenuated cell death triggered by $\mathrm{H}_{2} \mathrm{O}_{2}$. Thus, a slight alteration in the activity of caspase-8 appeared to have strong impact on the pro-apoptotic pathway in $\mathrm{H}_{2} \mathrm{O}_{2}$-treated lung cancer cells. These results also indicated that both mitochondrial and cell death receptor pathways were mutually required for the entire induction of apoptosis in $\mathrm{H}_{2} \mathrm{O}_{2}$-treated lung cancer cells. It would be important to ascertain how $\mathrm{H}_{2} \mathrm{O}_{2}$ affects the cell death receptor pathway to induce apoptosis in lung cancer cells. Concerning $\operatorname{MMP}\left(\Delta \Psi_{\mathrm{m}}\right)$, caspase inhibitors did not have any significant effect on the loss of MMP $\left(\Delta \Psi_{\mathrm{m}}\right)$ in $\mathrm{H}_{2} \mathrm{O}_{2}$-treated Calu- 6 and $\mathrm{A} 549$ cells. In addition, these inhibitors did not restore the decreased $\operatorname{MMP}\left(\Delta \Psi_{\mathrm{m}}\right)$ levels in $\mathrm{H}_{2} \mathrm{O}_{2}$-treated lung cancer cells. Instead, the caspase-9 inhibitor enhanced the decreased levels in these cells. It is plausible that the loss of $\operatorname{MMP}\left(\Delta \Psi_{\mathrm{m}}\right)$ following treatment with $\mathrm{H}_{2} \mathrm{O}_{2}$ 
activated various caspases related to mitochondrial and cell death receptor pathways, consequently inducing apoptosis, and the activation of caspases by $\mathrm{H}_{2} \mathrm{O}_{2}$ could not positively enhance the MMP $\left(\Delta \Psi_{\mathrm{m}}\right)$ loss. In addition, the loss of MMP $\left(\Delta \Psi_{\mathrm{m}}\right)$ induced by $\mathrm{H}_{2} \mathrm{O}_{2}$ may not be enough to completely provoke apoptosis in Calu- 6 and A549 cells under the downregulation of caspase activity.

In conclusion, $\mathrm{H}_{2} \mathrm{O}_{2}$ inhibited the growth of lung cancer cells through cell death and G1-phase arrest of the cell cycle. Calu-6 and A549 cell death caused by $\mathrm{H}_{2} \mathrm{O}_{2}$ resulted from necrosis, as well as caspase-dependent apoptosis (Fig. 7). The present results provide useful information to comprehend the cytotoxicological effect of exogenous $\mathrm{H}_{2} \mathrm{O}_{2}$ on lung cancer cells in regards to cell growth and death. In addition, novel strategies for the treatment of lung cancer based on the use of $\mathrm{H}_{2} \mathrm{O}_{2}$ may be helpful in reducing the mortality related to this malignancy.

\section{Acknowledgements}

Not applicable.

\section{Funding}

The present study was supported by a grant from the National Research Foundation of Korea (NRF) funded by the Korean government (MSIP; 2016R1A2B4007773) and supported by the 'Research Base Construction Fund Support Program' funded by Chonbuk National University in 2018.

\section{Availability of data and materials}

All data generated or analyzed during this study are included in this published article.

\section{Authors' contributions}

WHP was the sole contributor to the conception and design, acquisition of data, analysis and interpretation of data and writing of the manuscript. WHP is accountable for all aspects of the work in ensuring that questions related to the accuracy or integrity of any part of the work are appropriately investigated and resolved.

\section{Ethics approval and consent to participate}

Not applicable.

\section{Patient consent for publication}

Not applicable.

\section{Competing interests}

The author declares that he has no competing interests.

\section{References}

1. Gonzalez C, Sanz-Alfayate G, Agapito MT, Gomez-Niño A, Rocher A and Obeso A: Significance of ROS in oxygen sensing in cell systems with sensitivity to physiological hypoxia. Respir Physiol Neurobiol 132: 17-41, 2002.
2. Baran CP, Zeigler MM, Tridandapani S and Marsh CB: The role of ROS and RNS in regulating life and death of blood monocytes. Curr Pharm Des 10: 855-866, 2004.

3. Zorov DB, Juhaszova M and Sollott SJ: Mitochondrial ROSinduced ROS release: An update and review. Biochim Biophys Acta 1757: 509-517, 2006

4. Zelko IN, Mariani TJ and Folz RJ: Superoxide dismutase multigene family: A comparison of the CuZn-SOD (SOD1), Mn-SOD (SOD2), and EC-SOD (SOD3) gene structures, evolution, and expression. Free Radic Biol Med 33: 337-349, 2002.

5. Wilcox CS: Reactive oxygen species: Roles in blood pressure and kidney function. Curr Hypertens Rep 4: 160-166, 2002.

6. Chen TJ, Jeng JY, Lin CW, Wu CY and Chen YC: Quercetin inhibition of ROS-dependent and -independent apoptosis in rat glioma C6 cells. Toxicology 223: 113-126, 2006.

7. Dasmahapatra G, Rahmani M, Dent P and Grant S: The tyrphostin adaphostin interacts synergistically with proteasome inhibitors to induce apoptosis in human leukemia cells through a reactive oxygen species (ROS)-dependent mechanism. Blood 107: 232-240, 2006.

8. Wallach-Dayan SB, Izbicki G, Cohen PY, Gerstl-Golan R, Fine A and Breuer R: Bleomycin initiates apoptosis of lung epithelial cells by ROS but not by Fas/FasL pathway. Am J Physiol Lung Cell Mol Physiol 290: L790-L796, 2006.

9. Sarsour EH, Kumar MG, Chaudhuri L, Kalen AL and Goswami PC: Redox control of the cell cycle in health and disease. Antioxid Redox Signal 11: 2985-3011, 2009.

10. Budihardjo I, Oliver H,Lutter M, Luo X and Wang X: Biochemical pathways of caspase activation during apoptosis. Annu Rev Cell Dev Biol 15: 269-290, 1999.

11. Mehmet H: Caspases find a new place to hide. Nature 403: 29-30, 2000.

12. Hengartner MO: The biochemistry of apoptosis. Nature 407: 770-776, 2000

13. Hinz B, Phan SH, Thannickal VJ, Prunotto M, Desmoulière A, Varga J, De Wever O, Mareel M and Gabbiani G: Recent developments in myofibroblast biology: Paradigms for connective tissue remodeling. Am J Pathol 180: 1340-1355.

14. Rhee SG, Kang SW, Jeong W, Chang TS, Yang KS and Woo HA: Intracellular messenger function of hydrogen peroxide and its regulation by peroxiredoxins. Curr Opin Cell Biol 17: 183-189, 2005.

15. Vilhardt F and van Deurs B: The phagocyte NADPH oxidase depends on cholesterol-enriched membrane microdomains for assembly. EMBO J 23: 739-748, 2004.

16. Park WH: The effects of exogenous $\mathrm{H}_{2} \mathrm{O}_{2}$ on cell death, reactive oxygen species and glutathione levels in calf pulmonary artery and human umbilical vein endothelial cells. Int J Mol Med 31: 471-476, 2013.

17. Park WH: Exogenous $\mathrm{H}_{2} \mathrm{O}_{2}$ induces growth inhibition and cell death of human pulmonary artery smooth muscle cells via glutathione depletion. Mol Med Rep 14: 936-942, 2016.

18. Han YH, Kim SZ, Kim SH and Park WH: Pyrogallol inhibits the growth of lung cancer Calu- 6 cells via caspase-dependent apoptosis. Chem Biol Interact 177: 107-114, 2009.

19. Park WH, Seol JG, Kim ES, Hyun JM, Jung CW, Lee CC, Kim BK and Lee YY: Arsenic trioxide-mediated growth inhibition in MC/CAR myeloma cells via cell cycle arrest in association with induction of cyclin-dependent kinase inhibitor, p21, and apoptosis. Cancer Res 60: 3065-3071, 2000.

20. Park WH: Anti-apoptotic effect of caspase inhibitors on $\mathrm{H}_{2} \mathrm{O}_{2}$-treated $\mathrm{HeLa}$ cells through early suppression of its oxidative stress. Oncol Rep 31: 2413-2421, 2014.

21. You BR, Kim SH and Park WH: Reactive oxygen species, glutathione, and thioredoxin influence suberoyl bishydroxamic acid-induced apoptosis in A549 lung cancer cells. Tumour Biol 36: 3429-3439, 2015.

22. Yang J, Liu X, Bhalla K, Kim CN, Ibrado AM, Cai J, Peng TI, Jones DP and Wang X: Prevention of apoptosis by Bcl-2: Release of cytochrome c from mitochondria blocked. Science 275: 1129-1132, 1997.

23. Han YH, Kim SH, Kim SZ and Park WH: Antimycin A as a mitochondria damage agent induces an $\mathrm{S}$ phase arrest of the cell cycle in HeLa cells. Life Sci 83: 346-355, 2008.

24. Han YH, Kim SZ, Kim SH and Park WH: Pyrogallol inhibits the growth of human lung cancer Calu- 6 cells via arresting the cell cycle arrest. Toxicol In Vitro 22: 1605-1609, 2008. 